\title{
Job performance expectations and perceptions of retail employees: Cognitive dissonances between self-reports and supervisor-ratings
}

\author{
A. Tay ${ }^{a}$, C. Lees ${ }^{b}$ and O. Lin Dar *

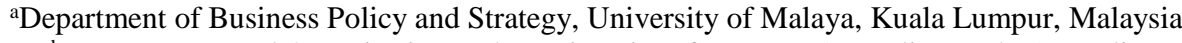 \\ ${ }^{b}$ Management and Organisations, The University of Western Australia, Perth, Australia \\ ${ }^{\mathrm{c}}$ Department of Business Policy and Strategy, University of Malaya, Kuala Lumpur, Malaysia \\ *To whom all correspondence should be addressed \\ lindar@um.edu.my
}

\begin{abstract}
Primary data was obtained from six retail outlets of a large global retailer to determine the self-reported job performance expectations (E) and perceptions (P) of 292 employees and the perceptions of 106 supervisors about their subordinates' actual job achievements. Unlike past studies, the focus of this study was on internal rather than the ubiquitous external customers' views on the performance quality and productivity of retail employees. The survey revealed that employees' performance expectations were much higher than their self-reported and the supervisors' perceptions of employees' performance. Although there were marginal differences in the mean scores between employees' and supervisors' perceptions, the average differences between the retail employees' expectations and their self-reported perceptions $\left(\mathrm{E}_{\mathrm{e}}-\mathrm{Pe}_{\mathrm{e}}\right.$ values), as well as between their expectations and the supervisors' perceptions ( $E_{e}-P_{s}$ values) of employees' performance were between 0.82 and 1.57. Using Anderson's (1973) expectation disconfirmation theory (EDT) this article analyses and discusses the cognitive dissonance between two performance evaluators.
\end{abstract}

\section{Introduction}

Retail businesses are under constant pressure to cope with smaller profits and more vulnerable markets due to intense competition (McLean, 2006). Globally, retailers are experiencing rising costs and shareholders' expectations of higher dividends. To remain sustainable in sluggish economies whereby consumers purchase prudently, retailers are compelled to minimise their operation costs and offer value-added services by enhancing the performance quality and productivity of their internal resources.

Early studies on the performance of services industry have focused more on optimising their economic benefits through enhancing the satisfaction and loyalty of external rather than the internal customers. These are widely documented in the services, marketing, retailing, and consumer behaviour journals and books (e.g., Bishop-Gagliano \& Hathcote, 1994; Bitner, Booms, \& Tetreault, 1990; Coye, 2004; Heskett, Sasser, \& Schlesinger, 1997, 2003; Netemeyer \& Maxham III, 2007; Zeithaml, Berry, \& Parasuraman, 1990). As services are intangible, customers tend to evaluate the quality of services by observing and experiencing the behaviours and attitudes of employees during their service encounters (Schneider \& Bowen, 1993).

In practice, while most service organisations acknowledge that employees are crucial for their overall successes, not all concede that they are more important than the external customers. Comparatively, it is the customers' rather than staff's needs that seemed to be the main organisational focus despite increasing empirical evidence that customers' perceptions of service quality and satisfaction are positively related to their service encounters with employees (e.g., Bitner et al., 1990; Coye, 2004; Heskett et al., 1997, 2003; Jiang, Klein, Roan, \& Lin, 2000; Tsaur \& Lin, 2004; Netemeyer \& Maxham III, 2007).

The search for more theoretical and practical performance motivators of service employees continues and this study is just one of such initiatives. Like customers, employees have their own performance expectations (what they hope to achieve) and perceptions of accomplishment (what they are able to achieve). When management commits to clearly explain their specific roles and how they could each contribute towards the success of organisations, they would likely do their best (Schneider \& Bowen, 1993). Employees are capable of setting their own job performance standards and targets that they expect to achieve them well.

When employees develop their own job performance expectations, they would also welcome the opportunity to assess their accomplishments - they want management to trust their judgements instead of stereotypically rely on the opinions of either their supervisors or customers. In this study, the employees and their immediate supervisors from all of the six outlets of a large international retailer were asked to evaluate the job performance of employees.

Most past studies in services marketing and services management used Parasuraman, Zeithaml, and Berry's (1988) 22-item service quality (SERVQUAL) measures to determine customers' service expectations (E) and perceptions $(\mathrm{P})$. The cognitive dissonances or the E-P gaps 
were then calculated to establish the level of customer satisfaction (Parasuraman, Berry, \& Zeithaml, 1991; Zeithaml et al., 1990). The authors defined customers' service quality expectations as their "desires or wants" and their perceptions as how they perceive service providers "should" rather than "would" deliver their services. The SERVQUAL measures have since been widely adapted to examine customers' perceptions of superior and inferior service quality in different types of businesses and context.

This study adapted Parasuraman et al. $(1988,1991)$ service quality concept by using several performance measures to establish the gaps between retail employees' and supervisors' expectations and perceptions of employees' job performance. Instead of obtaining the external customers' opinions, we examined the gaps between the internal customers' pre(expectations) and post- (perceptions) service performance quality and productivity experiences. Based on Parasuraman et al. (1988, 1991) similar arguments, this research hypothesised that the larger the E-P gaps for each of the service performance sub-measures, the higher would be the unmet expectations of employees. Ultimately, this could affect their future contributions and the overall performance of organisations.

\section{Research objectives and questions}

There is currently a dearth of published literature on the delivery of service quality and productivity as perceived by internal customers such as employees and supervisors. This research gap was addressed by determining the job performance quality and productivity expectations (E) of employees as well as the self-ratings and supervisors' perceptions $(\mathrm{P})$ of the actual job performance of employees. The dyadic study also measured the direction and size of the expectations-perceptions gaps $\left(\mathrm{E}_{\mathrm{e}}-\mathrm{P}_{\mathrm{e}}\right.$ and $\left.\mathrm{E}_{\mathrm{e}}-\mathrm{P}_{\mathrm{s}}\right)$ by comparing the mean scores ratings of the survey participants. The overall motivation of this article was to add to existing literature on the performance of service employees in general, and retail staff in particular. The following were three of the main research questions:

1. To what extent do employees' expectations of their performance quality and productivity differ from the perceptions of their actual performance $\left(E_{e}-P_{e}\right)$ ?

2. To what extent do employees' expectations of their performance quality and productivity differ from their supervisors' perceptions of the employees' actual performance $\left(\mathrm{E}_{\mathrm{e}}-\mathrm{P}_{\mathrm{s}}\right)$ ?

3. To what extent do employees' and supervisors' perceptions of employees' actual performance quality and productivity differ $\left(\mathrm{P}_{\mathrm{e}}-\mathrm{P}_{\mathrm{s}}\right)$ ?

Specifically, this article highlights the size (E-P gaps) and direction of cognitive dissonances in employee performance as perceived by employees and their immediate supervisors. The purpose is to inspire and create new interests in researchers and human resource professionals to contribute more innovative ways to motivate and improve the performance of service employees. Future researchers could for example, determine the extent to which the magnitude of E-P gaps are related to different types of employee behaviours and attitudes - such as their job motivation, job satisfaction, commitment, extra- and in-role behaviours, counter-productive behaviours, absenteeism as well as their turnover intentions.

\section{Literature review}

Until recently, most service organisations have focused more on delighting their external than internal customers. However, the performance and contribution of service employees deserve more attention from management as they could affect service delivery and customer satisfaction (Camps Luna-Arocas, 2009; Malhotra \& Mukherjee, 2004; McLean, 2006; Netemeyer \& Maxham III, 2007; Tsaur \& Lin, 2004). Past studies on services found significant and positive relationships between the performance of employees and external customers' perceptions of service quality (e.g., Bartel, 2004; Batt, Colvin, \& Keefe, 2002; Bitner et al., 1990; Liao \& Chuang, 2004; Schneider \& Bowen, 1993; Tsaur \& Lin, 2004). Others added that happy employees are contagious and they could make customers happy too (e.g., Coye, 2004; Heskett et al., 1997, 2003; Jiang et al., 2000; Klose \& Finkle, 1995; Masterson, 2001).

Heskett et al. (1997, 2003) used their profit-chain and valuechain models to define how satisfied service employees could delight their customers, and in return get them to remain loyal, make repeat purchases, and engage in positive wordof-mouth advertising. Masterson (2001) described how employees' satisfaction could cascade down and satisfy the needs of customers. As intangible services are produced and consumed concurrently, service employees' responsiveness, reliability, empathy, and efficiency are reportedly significant and positively related to customers' perceptions of service quality and satisfaction (Jiang et al., 2000; Klose \& Finkle, 1995; Parasuraman et al., 1988, 1991; Teas, 1993, 1994; Zeithaml et al., 1990). Unhappy employees and their indifferent attitudes towards customers could drive them to other service providers (Heskett et al., 2003).

Employees who are entrusted with more responsibility and authority, and are held accountable for their job outcomes are likely to be more involved and committed to their jobs (Becker \& Huselid, 1998; Camps \& Luna-Arocas, 2009; Schneider \& Bowen, 1993). In general, the authors encourage management to clearly communicate the organisational performance targets and goals during the orientation session and throughout their socialisation process. They posit that when employees are able to see how they can fit in and contribute constructively towards achieving the goals, they would likely set their personal performance targets and aim to achieve them.

\section{Individuals' expectations}

According to Higgs, Polonsky, and Hollick (2005; 50), "Expectations are important concepts because they form the frame of reference for satisfaction judgements." They 
described expectations as the pre-thoughts of some future performance that could be fixed somewhere between the ideal and realistic levels. They however, acknowledged that individuals are capable of setting their expectations at just the satisfactory or adequate levels to avoid stressing and stretching their limited resources to achieve them.

Like Higgs et al. (2005), Johnson, Nader, and Fornell (1996) emphasised that expectations are not constant but dynamic; individuals could change them as they receive more information about the goods and services of interest. Higgs et al. (2005) explained that customers, especially the new ones, are often unclear about their own expectations prior to service encounters. As they participate more in the purchasing process, they would become more familiar and experienced, and they are likely to fine-tune their expectations. Johnson et al. (1991) on the other hand, reported that when bank loan applicants received minimum or unclear information about the banks' services, they were dissatisfied because of their unmet expectations. Conversely, when the banks provided more information about their services, the customers recorded higher levels of satisfaction because their expectations were met.

According to Higgs et al. (2005) individuals with limited exposure and experience in complex services (like visiting art galleries and museums) would have comparatively lower expectations than those who have had prior experience and information (such as from past visits and advertising in the mass media). In their study of 550 art museum visitors, they found that the visitors had first pre-set and then changed their expectations after making the actual visits to the museum. They established that customers could cognitively refine their service expectations based on the additional information they obtain during service encounters. They advised service providers not to be discouraged if their services were below the expectations of individuals; it is a learning process and there will be enough time to improve on their service delivery and meet the needs of customers.

Therefore, when and how expectations are measured have important research implications (Higgs et al., 2005; Johnson et al., 1996). How expectations are formed would depend on the type and amount of information and cues that individuals use to develop their expectations. Higgs et al. (2005) noted that forecasted expectations recalled after consumption are not the same as those captured prior to consumption. They argued that past researchers have inaccurately used recalled expectations from post-encounter experiences as proxies to forecast expectations. Spreng and Droge (2001) established that only the forecasted or pre-encounter expectations are the true expectations. In their experimental study, they succeeded in managing the expectations and satisfaction of customers by manipulating information about the products' attributes and quality. They however cautioned marketers not to provide customers with inaccurate information by either understating or overstating the attributes and qualities of their products as they could backfire and lower the satisfaction of customers instead.

\section{Individuals' perceptions}

Like Jiang et al. (2000), Higgs et al. (2005) adopted the social perception theory to explain the opinions individuals have about others and on various matters. They explained that, "...people develop their own schema, a cognitive framework for understanding the external world" (p. 62). Diverse job types (e.g., manufacturing and services) and individual characteristics (e.g., age, gender, ethnicity, designation, and education), they said, are closely related to the development of individuals' perceptions. In addition, perhaps national, social, and organisational cultural differences could also be related to individuals' perceptions and decisions.

Jiang et al. (2000) explicitly described perceptions as the cognitive process that individuals actively engage in by observing, encoding, storing, and retrieving information about others. They recognised that as individuals rarely share the same views about others and on common matters, perceptual differences between them are inevitable. In their U.S. study, they asked the users of information systems (IS) to evaluate the IS employees' quality of service delivery, and the latter to evaluate their own job performance. Although, they found significant and positive correlations between the satisfaction of IS users and the performance of IS employees, their perceptions of service quality delivery varied because of differences in their demographic characteristics, needs, experience, and expectations.

While some authors propose that perceptions alone are good absolute predictors of service quality, others disagree because they are unable to fully explain the underlying complex structure of service delivery (e.g., Klose \& Finkle, 1995; Teas, 1993, 1994). Boulding, Kalra, Staclin, and Zeithaml (1993) submit that expectations are the precursors to perceptions and Johnson et al. (1996) report that expectations co-vary with customers' satisfaction. As satisfaction is abstract, authors have in the past used proxies such as the disconfirmation of expectations rather than direct perception ratings to determine if customers are satisfied or dissatisfied with the services they received (e.g., Johnson \& Fornell, 1991; Johnson et al., 1996).

\section{Expectations-perceptions (E-P) gaps}

The model of met and unmet expectations, according to Oliver (1980), is grounded on Anderson's (1973) expectation disconfirmation theory (EDT). Like other authors (e.g., Harvey et al., 2007), he used this theory to determine the differences between individuals' expectations and perceptions of service delivery and their levels of satisfaction. In management, Harvey et al. (2007) used EDT to highlight the importance of managing the expectations of expatriate managers by providing them with realistic overseas job previews before they leave for their foreign job postings. Failure to do so could make them less committed and dissatisfied, resulting in an early departure from their foreign assignments. 
McLean (2006) posits that the nature and size of individuals' expectations and perceptions about the effectiveness of HR functions would generally rest on who owns and have more power in the organisation. They found that unlike the HR professionals, the operations managers had higher expectations but lower ratings in their perceptions about the importance of HR functions and roles of their HR counterparts. In contrast, the HR professionals rated the HR functions and their personal contributions, higher.

Wright, Gardner, Moynihan, Park, Gerhart, and Delery (2001) reported that both the line and HR executives had similar ratings about the importance of HR functions in organisations. However, compared to their HR counterparts, the line executives had lower perceptions about the effectiveness of HR policies and practices. Wright et al. attributed the predictable outcomes to line managers' ignorance about the major role and contributions of HR departments. They added that line managers tend to consider themselves better than their HR colleagues in contributing towards the strategic decisions and success of organisations.

While employees' expectations of their performance could be shaped by their past experiences, personal successes, motivation, commitment, and past accomplishments, these have not been well documented in academic literature. Like other stakeholders in the organisation, employees are keen to achieve their own and that of their supervisors' and customers' expectations. We concur with Netemeyer and Maxham III (2007) that the existence of cognitive discrepancies between employees' job performance expectations and perceptions of their actual achievements could affect their future motivation to perform.

Management could therefore provide relevant resources sufficiently to ensure that employees are able to achieve their performance expectations and to minimise the perceptionexpectation gaps (Liao \& Chuang, 2004). If the unmet performance expectations of employees are prolonged, they could potentially compromise on their service quality delivery, productivity, and undermine the prospective effectiveness and competitiveness of service organisations (Heskett et al., 2003).

\section{Evaluators of job performance}

As jobs become more complex and multidimensional, so has the popularity of multi-rater or 360 degrees employee performance evaluation by supervisors, peers, subordinates, and employees (Goffin \& Gellatly, 2001). In practice, organisations often rely on supervisors or customers to evaluate the performance of employees for administrative (such as for pay revisions) and developmental (such as for training and career development) purposes. However, instead of relying on the evaluation of external customers on staff's job performance, we chose to obtain employees' and their supervisors' opinions as they are the main actors in the service delivery process. Like Schneider and Bowen (1993), we maintain that employees are just as competent and well- placed as their supervisors in assessing the performance of employees.

As literature continues to deliberate on the importance and effectiveness of a diverse source of employee performance evaluators, to date reports on the value and validity of selfratings compared to supervisor-ratings are mixed and inconclusive (Netemeyer \& Maxham III, 2007; Patiar \& Mia, 2008). While some authors have identified significant differences in their mean rating scores (e.g., Scullen, Mount, $\&$ Goff, 2000), others have reported their similarities (e.g., Heneman, 1974). However, most of the studies are dated and we have to some extent re-examined if subordinates and supervisors have similar or dissimilar employee performance mean rating scores.

The rater goal theory, according to Murphy, Cleveland, Skatteebo, and Kinney (2004), explains how subordinates' and supervisors' performance assessments could differ because of their different personal objectives and interpretations of organisational goals. Patiar and Mia (2008, p. 54) noted that organisational factors (e.g., human resource policies, leadership styles, and organisational structure, culture and climate) and individual characteristics (e.g., personality, traits, behaviours, and interpersonal relationships) could affect raters' evaluation of employees' performance.

Specifically, Patiar and Mia (2008) found significant differences between how the general managers (GMs) of 164 four and five star hotels and resorts in Australia rated the performance of their department managers (DMs) and DMs' self-ratings of their own performance. Levy and Sharma (1993) observed that while retail supervisors scored the performance of their sales personnel mostly around the midscale, the latter rated their own performance significantly higher. Interestingly, they noted that the supervisors' ratings were more accurate and valid, as they had reason to suspect that the sales personnel had over-rated their own performance.

\section{Research methods}

Studies in services marketing and management have in the past used SERVQUAL measures to determine the cognitive gaps between external customers' expectations and perceptions of service quality. To the best of the authors' knowledge, none have determined the cognitive dissonances between employees' job performance expectations and perceptions in the retail industry. This study extended the preand post-experience cognitive gaps arguments by determining the level of retail employees' expectations on several subjective performance measures and compared them with their self-reported and supervisors' perceptions of employees' achievements. Their expected and perceived mean scores were obtained and the size of E-P gaps within and between employees and their supervisors were calculated. 


\section{Sample size}

In this research, data from 292 service employees (mostly frontline staff) and 106 supervisors from all the 6 retail outlets of a large international retailer were gathered in Malaysia. The first author personally distributed the questionnaires at the six retail outlets and collected most of the completed forms onsite. However, some of the survey participants had requested for more time and they used pre-postage paid envelopes to return their completed survey forms. Participation in the survey was voluntary and anonymities of the participants were carefully maintained throughout the data collection and analysis stages.

\section{Employee performance quality and performance productivity measures}

Singh's (2000) 17-item performance quality (PERFQ) and 7item performance productivity (PERFP) scales to determine the participants' perceived job performance expectations and perceptions were adopted. The PERFQ items measured employees' Trust (3 items), Promptness ( 5 items), Reliability (5 items), and their Individualised Attention towards customers (4 items). The internal reliabilities of the fourdimension performance quality (PERFQ) scales in Singh's original study were $.89, .89, .77$, and .93 , respectively. The original Cronbach's alphas for his two-dimension PERFP measures were .89 and .92 , for Contact Output (4 items) and Backroom Work (3 items), respectively.

Like Singh (2000), the survey participants were asked to evaluate the quality and productivity of employees' performance relative to that of their colleagues or co-workers in the same unit or department. They rated the measures based on a seven-point Likert scale, whereby $1=$ poor performance (bottom 20\%), 3 = average performance, and $7=$ excellent performance (top 5\%). This scale was slightly modified from Singh's original 7-point rating scale which had endpoints of "bottom 20\%" and "top 5\%." On the request of the participants from our pilot study, we added $3=$ average performance, in the Likert scale to improve its clarity.

The PERFP and PERQ items were judiciously adapted and rephrased (without changing their meanings) to enable supervisors to evaluate the performance of their subordinates based on similar performance measures. Both the employee and supervisor questionnaires were back translated from English to Bahasa Malaysia for the benefit of the survey participants who were not fluent in the English language. The following were some examples of the PERFQ and PERFP items:

PERFQ: Compared to your colleagues, how would you rate yourself in.........

- Overall, developing customer trust and confidence in your service

- Overall, consistently providing prompt service to all of your customers

- Overall, performing your job dependably \& accurately
PERFP: Compared to your colleagues, how would you rate yourself in.........

- Overall customer contact (e.g., time spent interacting with customers)

- Overall performance in reaching objectives

- Providing accurate and complete paperwork

Besides the employees, the supervisors were asked to evaluate their subordinates' performance. Compared to other stakeholders, the supervisors were physically nearest to employees and they were therefore well-positioned to accurately assess their employees' performance (Becker \& Huselid, 1998). The supervisors' evaluations of employee performance were included to also avoid the possibility of common method variance in primary research (Podsakoff, MacKenzie, Lee, \& Podsakoff, 2003).

\section{Measuring the P-E gaps}

Similar to Netemeyer and Maxham III (2007), we measured the performance expectations and perceptions of service employees at the individual-level. Malhotra and Mukherjee (2004) reaffirmed that employees are capable of evaluating the effectiveness of HRM practices and their own performance objectively. They added that frontline employees and those who are in direct contact with customers could accurately observe and measure their own performance and evaluate their impact on customer satisfaction.

Like Oliver (1980) and Harvey et al. (2007), Anderson's (1973) expectation disconfirmation theory (EDT) was adopted to determine the gaps in job performance perceptions and expectations. Like them, this research hypothesised that when the perceptions of actual experiences of individuals are higher than their expectations $(\mathrm{P}>\mathrm{E})$, there would be positive disconfirmation. Conversely, there would be negative disconfirmation when the perceptions of individuals are lower than their expectations $(\mathrm{E}>\mathrm{P})$.

\section{Data analysis procedure}

The SPSS 22.0 for Windows programme was used to summarise the demographic characteristics of employees and supervisors, the mean values of employees' self-assessments of their performance expectations and perceptions, as well as supervisors' ratings or perceptions of their subordinates' actual job performance. The E-P gaps were calculated based on mean values differences between and within the survey participants' performance ratings. The exploratory factor analysis (EFA) and reliability tests were also used to determine the strength of the research measures.

\section{Research findings}

\section{Demographic characteristics of employees and supervisors}

In summary, 58\% of the 292 employees and $75 \%$ of the 106 supervisors who participated in the survey were males. The 
average ages of the employees and their supervisors were 28 and 33 years old, respectively. Most of the employees (84\%) were frontline staff, while their supervisors were mostly executives $(67 \%)$, managers $(15 \%)$, and senior managers (3\%). While $31 \%$ of the supervisors had diplomas and $23 \%$ of them were tertiary degree holders, about $75 \%$ of the employees had "O" level or secondary school qualifications. Accordingly, the academically more qualified supervisors were paid more than their subordinates; about $88 \%$ of the supervisors earned gross monthly salaries of above RM2000 and $89 \%$ of the employees earned less than RM2000 per month. The average tenure of the retail employees and their supervisors were 3.1 and 4.5 years, respectively.

A principal factor analysis with varimax rotation clearly identified two distinct factors that corresponded with Singh's (2000) original 17-item PERFQ and 7-item PERFP measures. The average internal reliabilities of the PERFQ and PERFP measures were .95 and .90 , respectively; they were above the recommended threshold of .70 (Hair, Black, Babin, Andersen, \& Tatham, 2006) and slightly higher than that reported in Singh's original study.

The $E_{e}-P_{e}$ gaps

Table 1 summarises the mean values of all the performance quality (PERFQ) and productivity (PERFP) sub-scales that measured the expectations of employees and theirs and supervisors' perceptions of the job performance of employees. The table shows that the expectations of employees (mean values ranging between 5.80 and 6.47) were much higher than their perceptions of actual performance (mean values ranging between 4.59 and 5.63). The negative disconfirmation expectation gaps $\left(E_{e}>P_{e}\right)$ were between 0.82 and 1.33 as reported in the last column of Table 1 and exhibited graphically in Figure 1.

Table 1: Mean values of employees' self-reported expectations and their perceptions of performance quality and productivity

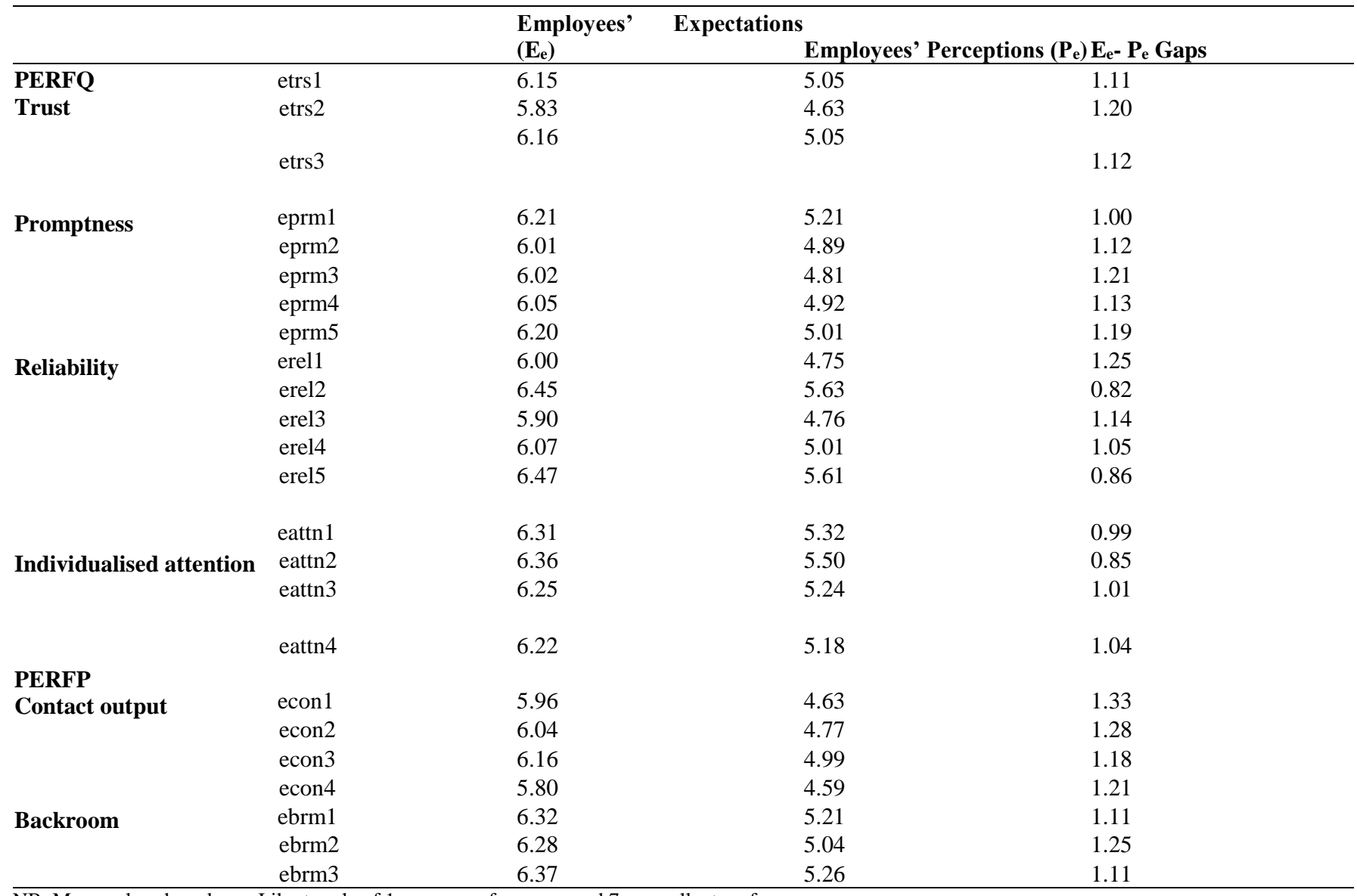

NB. Mean values based on a Likert scale of $1=$ poor performance and $7=$ excellent performance

\section{The $E_{e}-P_{s}$ gaps}

Table 2 reveals differences in ratings between the employees' self-reported performance expectations (mean values between 5.80 and 6.47) and their supervisors' perceptions of their subordinates' actual performance (mean values between
4.52 and 5.26). The results showed that the supervisors' and employees' perceptions ratings were fairly similar, but they were lower than the expectations of employees. The last column of Table 2 summarises the negative disconfirmation results based on the evaluations of both groups of survey participants. 
The gaps in their mean values were between 1.03 and 1.57 , revealing that employees had higher expectations than their supervisors' perceptions of employee performance. The negative disconfirmation results $\left(E_{e}>P_{s}\right)$ seemed to suggest that employees perceived they have the potentials to perform and contribute more towards the effectiveness of organisations but they lacked the opportunity to do so. This was one of the main contributions from the study that required prompt managerial action.

Table 2: Mean values of employees' self-reported expectations and supervisors' perceptions of employees' performance quality and productivity

\begin{tabular}{|c|c|c|c|c|}
\hline & & $\begin{array}{l}\text { Employees' } \\
\text { Expectations }\left(\mathrm{E}_{\mathrm{e}}\right)\end{array}$ & $\begin{array}{l}\text { Supervisors' } \\
\text { Perceptions }\left(\mathbf{P}_{\mathrm{s}}\right)\end{array}$ & $\mathbf{E}_{\mathrm{e}}-\mathbf{P}_{\mathrm{s}}$ Gaps \\
\hline \multirow[t]{2}{*}{ PERFQ } & etrs1 & 6.15 & 5.08 & 1.07 \\
\hline & etrs2 & 5.83 & 4.61 & 1.21 \\
\hline \multirow[t]{2}{*}{ Trust } & & 6.16 & 4.88 & \\
\hline & etrs3 & & & 1.28 \\
\hline \multirow[t]{5}{*}{ Promptness } & eprm1 & 6.21 & 4.99 & 1.22 \\
\hline & eprm2 & 6.01 & 4.52 & 1.49 \\
\hline & eprm3 & 6.02 & 4.81 & 1.21 \\
\hline & eprm4 & 6.05 & 4.59 & 1.46 \\
\hline & eprm5 & 6.20 & 4.94 & 1.26 \\
\hline \multirow[t]{5}{*}{ Reliability } & erel1 & 6.00 & 4.87 & 1.14 \\
\hline & erel2 & 6.45 & 5.26 & 1.20 \\
\hline & erel3 & 5.90 & 4.63 & 1.27 \\
\hline & erel4 & 6.07 & 4.75 & 1.32 \\
\hline & erel5 & 6.47 & 5.09 & 1.38 \\
\hline \multirow[t]{4}{*}{ Individualised Attention } & eattn1 & 6.31 & 5.04 & 1.27 \\
\hline & eattn2 & 6.36 & 5.01 & 1.34 \\
\hline & eattn3 & 6.25 & 4.89 & 1.36 \\
\hline & eattn4 & 6.22 & 4.97 & 1.25 \\
\hline \multirow[t]{4}{*}{ Contact output } & econ1 & 5.96 & 4.85 & 1.11 \\
\hline & econ2 & 6.04 & 4.89 & 1.15 \\
\hline & econ3 & 6.16 & 5.03 & 1.13 \\
\hline & econ 4 & 5.80 & 4.57 & 1.23 \\
\hline \multirow[t]{3}{*}{ Backroom } & ebrm1 & 6.32 & 4.75 & 1.57 \\
\hline & ebrm2 & 6.28 & 5.25 & 1.03 \\
\hline & ebrm3 & 6.37 & 5.18 & 1.19 \\
\hline
\end{tabular}

NB. Mean values based on a Likert scale of $1=$ poor performance and $7=$ excellent performance

The $P_{e}-P_{s}$ gaps

Figure 1, graphically summarises the research findings. It shows that the mean values of employees' expectations (represented by the red lines) of their performance quality and productivity were much higher than their self-reported (blue lines) and supervisors' ratings (green lines) of the employees' actual job performance.

Overall, the opinion trends of employees' and supervisors' perceptions of the actual performance of employees were closely similar. Except for three minor instances, the mean values of the employees' self-reports were marginally higher than that of their immediate supervisors' ratings. Their almost similar performance perceptions ratings showed that the employees did not over-rate their own performance.

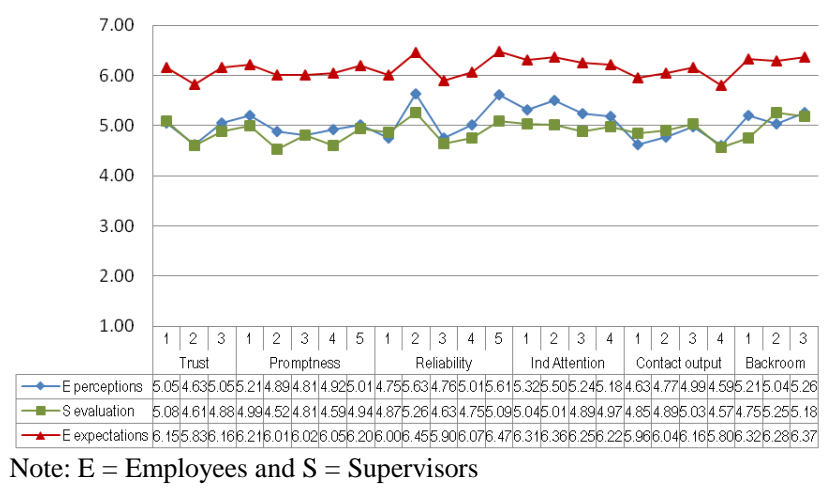

Figure 1. Employees' self- reported performance expectations and perceptions, and supervisors' perceptions of employees' actual performance quality and productivity 
The research findings also showed that irrespective of who evaluated the actual job performances of employees, there were cognitive dissonances or negative disconfirmation (E > P) between employees' expectations and perceptions of their performance quality and productivity. The employees' expectations were consistently higher than their supervisors' perceptions of employees' job performance. The magnitudes of their unmet performance expectations or negative disconfirmation (E-P) values were between 0.82 and 1.57 .

\section{Implications}

The research findings revealed that employees' ratings on multiple performance quality and productivity sub-measures were marginally higher than their immediate supervisors' evaluations (see Figure 1). Their fairly similar ratings on employees' job performance seemed to defy some past critiques in literature (e.g., Levy \& Sharma, 1993; Spector, 2006) and HR professionals that employees' self-reports are often unreliable because they tend to inflate their performance ratings.

Past claims that under-value self-reports must be contested. The survey of 292 employees showed that when employees had the opportunity to rate their actual performances higher, i.e., closer to the maximum score of 7 points, they did not. Their self-rating mean scores of 5.5 and less suggest that they were disciplined and responsible in evaluating their own job performances; they were based on what they perceived to be true. Besides, their scores were closely similar to their supervisors' perceptions, and we argue that employees are just as reliable, responsible, honest, and objective as their superiors in evaluating employee performance.

The nature of this study supported the reliability of our research findings and assertions. It was conducted by a neutral and independent party and not by an outsourced research team that was hired by the international retailer. This could have prompted the employees to provide their frank and objective opinions about their own performance; they knew they did not have to impress any party at all. In addition, right from the start, the survey participants were assured of their anonymities and that their responses were meant for research purposes only - they were not meant to be given to their management as inputs to determine each of their annual salary increase or promotion.

The results from this study therefore support the recommendations of more recent authors that employees should also be allowed to evaluate their own performance at work (Goffin \& Gellatly, 2001; Malhotra \& Mukherjee, 2004; Netemeyer \& Maxham, 2007; Schoorman \& Mayer, 2008). The survey results reaffirmed the credibility and trustworthiness of employees; they transcended past reservations and trepidations about using self-ratings in performance research and in measuring organisational effectiveness. The results have demonstrated that employees can be sincere and candid in their responses and if we treat them as responsible and reliable adults, they would respond and behave like one.
This study also revealed the presence of negative expectation disconfirmation $(\mathrm{E}>\mathrm{P})$ gaps in multiple employee performance (PERFQ and PERFP) measures. The employees could have perhaps over-promised and under-delivered in their performance, but their causes were beyond the scope of this study. This study did not examine how the expectations and perceptions of employees were formed as they seemed to have pitched their expectations fairly high (mean scores of 6.0 and above) and their perceptions, moderately. Most of the E-P gaps were above 1.0, irrespective of who evaluated the actual performance of employees (see Tables 1 and 2). Potentially, if the size and direction of the E-P gaps remain the same, or if their magnitudes continue to increase over time, they could frustrate and dissatisfy employees.

The E-P cognitive dissonances results seemed to reveal that employees in the six retail outlets had the potential to achieve or contribute more but it was unfortunate that management had overlooked or ignored their capabilities and desire to perform better. The onus was therefore on the international retailer to acknowledge and identify the E-P gaps within and between employees and their supervisors. They would have to determine if employees have either set their expectations (E) too high, or if they and their supervisors were too conservative in evaluating their perceptions (P). If so, management would have to take corrective measures to address them, accordingly.

In general, management's failure to recognise the presence of internal customers' E-P performance dissonances could demotivate employees and affect their future contributions towards organisational effectiveness. By proactively identifying and working towards narrowing the E-P gaps, they could provide employees with the resources and motivation to achieve their performance expectations. In practice, this could mean extending more time, money, raw materials, equipment, technology, and training to fully tap on their performance potentials and aspirations (Liao \& Chuang, 2004; McLean, 2006). McLean (2006) found that when employees received timely and appropriate training on how to be more approachable, helpful, and business-focused, they succeeded in achieving their personal and organisational expectations.

\section{Suggestions for future research}

The focus of this study was on the internal customers' (namely, employees and supervisors) expectations and perceptions of employee performance. Unlike Klose and Finkle (1995), this preliminary study did not establish the significant and positive relationships between the satisfaction of internal and external customers. Future research could extend this research to establish if the performance ratings from the two sources could predict several outcome measures. Netemeyer and Maxham III (2007), for example, determined if subordinates' self-ratings and supervisors' ratings of the in-role and extra-role behaviours of service employees could predict customer satisfaction and the effectiveness of word of mouth advertising in attracting new customers. 
This research has obtained the service performance feedbacks from only two internal sources, prospective studies could include the opinions of external stakeholders such as customers and suppliers. Future studies could also attempt to distinguish between the individuals' forecasted and ideal expectations (e.g., Higgs et al., 2005) and establish if they are related to employee and customer satisfaction, and organisational effectiveness. Prospective researchers could also examine if organisational, personal, cultural, and sectorial factors affect internal raters' perceptions and expectations of performance.

In addition, future research could determine the consequences of ignoring the E-P job performance gaps and their relationships with a wide range of employee attitudes, their work behaviours, and organisational outcomes. They could establish if smaller E-P gaps are significantly related to employees' job satisfaction, commitment, productivity, absenteeism rate, and intention to leave their organisations. Perhaps the larger the E-P gaps, for example, the lower would be the commitment of employees and the higher, their job dissatisfaction. There are costs implications if employees fail to perform and/or when organisations are unable to retain good employees. It would take an enormous amount of time and money to hire and train new staff to fit in their new roles and to perform. It is therefore more important for management to be pro-active than reactive in motivating employees to perform. In general, organisations and academics could collaborate more to establish the antecedents and consequences of meeting or exceeding the performance expectations of employees.

\section{Research limitations}

This study was cross-sectional in nature; the data sets were obtained from one timeframe and from the staff of only one international retailer. A longitudinal study that compares the job performance expectations and perceptions of not just employees and supervisors but of other stakeholders in the supply chain (e.g., suppliers, manufacturers, customers, etc.) would have enable the findings to be generalized across the retail and services industry. Besides, ideally data triangulation from at least three groups of evaluators such as from the employees, supervisors, and customers could have enhanced the quality and contribution of this study for the benefit of academia and service organisations.

Another limitation of this study was the size of the research samples. Staff from all the outlets of only one of the four major international retailers in the country had participated in the survey. Although, management from the three remaining large retailers were invited to join in the study, they declined to do so for multiple reasons. A wider sample size by including more survey participants from all the four major retail players in Malaysia would have made findings from inter-retailer instead of just the intra-retailer comparisons possible and more meaningful.

\section{Conclusion}

This dyadic study of 292 retail employees and 106 supervisors examined employees' self-ratings $\left(\mathrm{P}_{\mathrm{e}}\right)$ and supervisors' perceptions $\left(\mathrm{P}_{\mathrm{s}}\right)$ of employee performance vis-àvis the performance expectations of employees $\left(\mathrm{E}_{\mathrm{e}}\right)$. The research findings consistently revealed the presence of cognitive dissonances or gaps within and between what service employees have expected to perform and what they and their supervisors' perceived employees were able to achieve in their jobs. Specifically, the results showed that the performance expectations of employees were higher than they or even their supervisors believed they were able to achieve.

The outcomes from this research have also complemented dated findings (e.g., Heneman, 1974) on the close similarities in mean values between self-ratings and supervisors-ratings. The results from this study supported the reliability and accuracy of the two internal rater sources in evaluating employee performance. Although this initial research did not set out to empirically establish the relationships or congruence between external and internal employees' satisfaction, this could be done in the future. This preliminary empirical initiative has provided an initial platform and challenge for future studies to contribute towards the advancement of more innovative and sustainable performance management theories and practices for the benefit of the services industry, in general and retail business, in particular.

\section{References}

Anderson, E.W. 1973. 'Consumer dissatisfaction: The effects of disconfirmed expectancy on perceived product performance', Journal of Marketing Research, 10: 38-44.

Bartel, A.P. 2004. 'Human resource management and organizational performance: Evidence from retail banking', Industrial \& Labor Relations Review, 57(2): 181-203.

Batt, R., Colvin, A.J.S. \& Keefe, J. 2002. 'Employee voice, human resource practices, and quit rates: Evidence from the telecommunications industry', Industrial \& Labor Relations Review, 55(4): 573-593.

Becker, B.E. \& Huselid, M.A. 1998. 'High performance work systems and firm performance: A synthesis of research and managerial implications', Research in Personnel and Human Resources Management, 16: 53-101

Bishop-Gagliano, K. \& Hathcote, J. 1994. 'Customer expectations and perceptions of service quality in retail apparel speciality stores', Journal of Services Marketing, 8(1): 60-69.

Bitner, M.J., Booms, B.H. \& Tetreault, M.S. 1990. 'The service encounter: Diagnosing favourable and unfavourable incidents', Journal of Marketing, 54: 71-84.

Boulding, W., Kalra, A., Staclin, R. \& Zeithaml, V. 1993. 'A dynamic process of service quality: From expectations to behavioural intentions', Journal of Marketing Research, 30(1): 727. 
Chen, K.K., Chang, C.T. \& Lai, C.S. 2009. 'Service quality gaps of business customers in the shipping industry', Transportation Research, 45: 222-237.

Camps, J. \& Luna-Arocas, R. 2009. 'High involvement work practices and firm performance', International Journal of Human Resource Management, 20(5): 1056-1077.

Coye, R.W. 2004. 'Managing customer expectations in the service encounter', International Journal of Service Industry Management, 15(1): 54-71.

Goffin, R.D. \& Gellatly, I.R. 2001. 'A multi-rater assessment of organizational commitment: Are self-report measures biased?', Journal of Organizational Behavior, 22: 437-451.

Hair, J.F., Black, W.C., Babin, B.J., Andersen, R.E. \& Tatham, R.L. 2006. Multivariate data analysis, 7th ed. Upper Saddle River, NJ: Prentice-Hall International Inc.

Harvey, M.G., Buckley, M.R. \& Novicevic, M.M. 2007. 'The role of realistic job previews and expectation lowering procedures for expatriate managers', Journal of Diversity Management, 2(3): 13-22.

Heneman, H. 1974. 'Comparisons of self and superior rating of managerial performance', Journal of Applied Psychology, 59(5): 638-642.

Heskett, J.L., Sasser, W.E. \& Schlesinger, L.A. 1997. The service profit-chain. New York: The Free Press.

Heskett, J.L., Sasser, W.E. \& Schlesinger, L.A. 2003. The value profit-chain: Treat employees like customers and customers like employees. New York: The Free Press.

Higgs, B., Polonsky, M.J. \& Hollick, M. 2005. 'Measuring expectations: Forecast vs. ideal expectations. Does it really matter?', Journal of Retailing and Consumer Services, 12: 49-64.

Jiang, J.J., Klein, G., Roan, J. \& Lin, J.T.M. 2000. 'IS service performance: Self perceptions and user perceptions', Information \& Management, 38: 499-506.

Johnson, M.D. \& Fornell, C. 1991. 'A framework for comparing customer satisfaction across individuals and product categories', Journal of Economic Psychology, 12: 267-286.

Johnson, M.D., Nader, G. \& Fornell, C. 1996. 'Expectations, perceived performance, and customer satisfaction for a complex service: The case of bank loans', Journal of Economic Psychology, 17: $163-182$.

Klose, A. \& Finkle, T. 1995. 'Service quality and the congruency of employee perceptions and customer expectations: The case of an electric utility', Psychology \& Marketing, 12(7): 637-646.

Levy, M. \& Sharma, A. 1993. 'Relationships among measures of retail salesperson performance', Journal of the Academy of Marketing Science, 21(3): 231-238.

Liao, H. \& Chuang, A. 2004. 'A multilevel investigation of factors influencing employee service performance and customer outcomes', Academy of Management Journal, 47(1): 41-58.

Malhotra, N. \& Mukherjee, A. 2004. 'The relative influence of organisational commitment and job satisfaction on service quality of customer-contact employees in banking call centres', The Journal of Services Marketing, 18: 162-174.

Masterson, S.S. 2001. 'A trickle-down model of organizational justice: Relating employees' and customers' perceptions of and reactions to fairness', Journal of Applied Psychology, 86(4): 594604.

McLean, M. 2006. 'Evaluating the importance and performance of the human resources function: An examination of a medium sized Scottish retailer', Journal of Retailing and Consumer Services, 13: 143-156.

Murphy, K.R., Cleveland, J.N., Skattebo, A.L. \& Kinney, T.B. 2004. 'Raters who pursue different goals give different ratings', Journal of Applied Psychology, 89: 158-164.

Netemeyer, R.G. \& Maxham III, J.G. 2007. 'Employee versus supervisor ratings of performance in the retail customer service sector: Differences in predictive validity for customer outcomes', Journal of Retailing, 83(1): 131-145.

Oliver, R.L. 1980. 'A cognitive model of the antecedents and consequences of satisfaction decisions', Journal of Marketing Research, 17: 460-469.

Parasuraman, A., Berry, L.L. \& Zeithaml, V.A. 1991. 'Understanding customer expectations of service', Sloan Management Review, 32(3): 39-48.

Parasuraman, A., Zeithaml, V.A. \& Berry, L.L. 1988. 'SERVQUAL: A multiple-item scale for measuring consumer perceptions of service quality', Journal of Retailing, 54(1): 12-40.

Parasuraman, A., Zeithaml, V.A. \& Berry, L.L. 1994. 'Reassessment of expectations as a comparison standard in measuring service quality: Implications for further research', Journal of Marketing, 58(1): 111-124.

Patiar, A. \& Mia, L. 2008. 'The effect of subordinates' gender on the difference between self-ratings, and supervisors' ratings, of subordinates' performance in hotels', International Journal of Hospitality Management, 27: 53-64.

Podsakoff, P.M., MacKenzie, S.B., Lee. J.Y. \& Podsakoff, N.P. 2003. 'Common method biases in behavioural research: A critical review of the literature and recommended remedies', Journal of Applied Psychology, 88: 879-903.

Schneider, B. \& Bowen, D.E. 1993. 'The service organization: Human resources management is crucial', Organizational Dynamics, 21(4): 39-52.

Schoorman, F.D. \& Mayer, R.C. 2008. 'The value of common perspectives in self-reported appraisals: You get what you ask for', Organizational Research Methods, 1(1): 148-159.

Scullen, S., Mount, M. \& Goff, M. 2000. 'Understanding the latent structure of job performance ratings', Journal of Applied Psychology, 85(6): 956-970.

Singh, J. 2000. 'Performance productivity and quality of frontline employees in service organizations', Journal of Marketing, 64: 1534. 
Spector, P.E. 2006. 'Method variance in organizational research: Truth or urban legend?', Organizational Research Methods, 9(2): 221-232.

Spreng, R.A. \& Droge, C. 2001. 'The impact on satisfaction of managing attribute expectations: Should performance claims be understated or overstated?', Journal of Retailing and Consumer Services, 8: 261-274.

Teas, R.K. 1993. 'Expectations, performance and consumer's expectations of quality', Journal of Marketing, 57(3): 18-34.

Teas, R.K. 1994. 'Expectations as a comparative standard in measuring service quality: An assessment of re-evaluation', Journal of Marketing, 58(1): 132-138.

Tsaur, S.H. \& Lin, Y.C. 2004. 'Promoting service quality in tourist hotels: The role of HRM practices and service behavior', Tourism Management, 25: 471-481.

Wright, P.M., Gardner, T.M., Moynihan, L.M., Park, H.J., Gerhart, B. \& Delery, J.E. 2001. 'Measurement error in research on human resources and firm performance: Additional data and suggestions for future research', Personnel Psychology, 54: 875-901.

Zeithaml, V.A., Berry, L.L. \& Parasuraman, A. 1990. Delivering service quality: Balancing consumer perceptions and expectations. New York: The Free Press. 